\title{
dsRNA-induced changes in gene expression profiles of primary nasal and bronchial epithelial cells from patients with asthma, rhinitis and controls
}

Ariane H Wagener ${ }^{1 *}$, Aeilko H Zwinderman², Silvia Luiten ${ }^{3}$, Wytske J Fokkens ${ }^{3}$, Elisabeth H Bel ${ }^{1}$, Peter J Sterk ${ }^{1}$ and Cornelis M van Drunen ${ }^{3}$

\begin{abstract}
Background: Rhinovirus infections are the most common cause of asthma exacerbations. The complex responses by airway epithelium to rhinovirus can be captured by gene expression profiling. We hypothesized that: a) upper and lower airway epithelium exhibit differential responses to double-stranded RNA (dsRNA), and b) that this is modulated by the presence of asthma and allergic rhinitis.

Objectives: Identification of dsRNA-induced gene expression profiles of primary nasal and bronchial epithelial cells from the same individuals and examining the impact of allergic rhinitis with and without concomitant allergic asthma on expression profiles.

Methods: This study had a cross-sectional design including 18 subjects: 6 patients with allergic asthma with concomitant rhinitis, 6 patients with allergic rhinitis, and 6 healthy controls. Comparing 6 subjects per group, the estimated false discovery rate was approximately 5\%. RNA was extracted from isolated and cultured primary epithelial cells from nasal biopsies and bronchial brushings stimulated with dsRNA (poly(l:C)), and analyzed by microarray (Affymetrix U133+ PM Genechip Array). Data were analysed using R and the Bioconductor Limma package. Overrepresentation of gene ontology groups were captured by GeneSpring GX12.
\end{abstract}

Results: In total, 17 subjects completed the study successfully (6 allergic asthma with rhinitis, 5 allergic rhinitis, 6 healthy controls). dsRNA-stimulated upper and lower airway epithelium from asthma patients demonstrated significantly fewer induced genes, exhibiting reduced down-regulation of mitochondrial genes. The majority of genes related to viral responses appeared to be similarly induced in upper and lower airways in all groups. However, the induction of several interferon-related genes (IRF3, IFNAR1, IFNB1, IFNGR1, IL28B) was impaired in patients with asthma.

Conclusions: dsRNA differentially changes transcriptional profiles of primary nasal and bronchial epithelial cells from patients with allergic rhinitis with or without asthma and controls. Our data suggest that respiratory viruses affect mitochondrial genes, and we identified disease-specific genes that provide potential targets for drug development.

Keywords: Asthma, Rhinitis, Epithelium, Gene expression, dsRNA

\footnotetext{
*Correspondence: a.h.wagener@amc.uva.nl

'Department of Respiratory Medicine, Academic Medical Center, University of Amsterdam, Meibergdreef 9, 1105 AZ, Amsterdam, The Netherlands

Full list of author information is available at the end of the article
} 


\section{Background}

Viral respiratory tract infections are the most common cause of asthma exacerbations [1], with rhinovirus (RV) being the most prominent virus involved. Patients with asthma are not at increased risk of a viral infection as compared to healthy controls, but in case of an upper respiratory infection they are more prone to develop a lower respiratory tract infection with more severe symptoms [2]. This suggests that host characteristics are contributing to the clinical responses to virus infections in asthma.

The majority of patients with asthma is sensitized to environmental allergens, which is associated with allergic airways inflammation [3]. There is increasing evidence of interaction between viral infection and allergic sensitization, with increased risk for a more severe exacerbation if patients with asthma are atopic [4]. Since asthma and rhinitis co-exist to variable degrees [5], the host characteristics in upper and lower airways when encountering a respiratory virus are likely to vary to a similar extent. In order to develop effective interventions for the prophylaxis and treatment of virus-induced exacerbations in asthma, it is mandatory to map the responses of both upper and lower airways to respiratory viruses in patients with asthma and/or rhinitis.

The upper and lower airway epithelial layer is constantly exposed to viruses, bacteria and allergens, and represents the first line of defence. Experiments with nasal and bronchial epithelial cells from the same individuals suggested greater susceptibility of the lower airways to RV because of differences in electrical resistance and viral replication between upper and lower airway epithelium, though no differences were observed between asthma and healthy controls [6]. However, there is increasing evidence that pre-existing asthma affects epithelial cytokine responses to RV, such as impaired interferon (IFN) production and differences in expression of genes involved in immune response and airway remodelling [7-9]. Collectively, these studies suggest that the complex role of the airway epithelium in response to viruses is affected by asthma- and allergy-related changes in gene expression.

Double-stranded RNA (dsRNA) is produced during $\mathrm{RV}$ replication and is an important stimulus of the host immune response [10]. Therefore, we hypothesized a) that upper and lower airway epithelium exhibit differential responses to dsRNA infection and b) that this is modulated by the presence of asthma and allergic rhinitis. To that end, we aimed to compare dsRNA-induced gene expression profiles of cultured primary nasal and bronchial epithelial cells obtained from patients with asthma with concomitant allergic rhinitis, patients with allergic rhinitis alone, and healthy controls. The observed gene-expression profiles can be used to delineate the critical pathways that are operative in epithelial cells after virus infection in patients with and without pre-existing airways disease.

\section{Methods \\ Subjects}

In total, 18 subjects ( $>18$ y) were recruited for this study, which is part of a larger project [11]. The subjects comprised of three groups: 1) 6 subjects with allergic asthma with concomitant allergic rhinitis, 2) 6 subjects with allergic rhinitis, and 3) 6 healthy controls. Patients with asthma had episodic chest symptoms, controlled or partly controlled disease according to GINA-criteria [12] with airway hyperresponsiveness $\left(\mathrm{PC}_{20}\right.$ methacholine $\left.\leq 8 \mathrm{mg} / \mathrm{mL}\right)$ according to the standardized tidal volume method [13]. All subjects with allergic rhinitis had persistent, moderate to severe disease according to ARIA-criteria [14] with nasal symptoms for more than 4 days a week during more than 4 consecutive weeks. Atopic status was based on the presence of at least one positive skin prick test response ( $>3 \mathrm{~mm}$ wheal) to common allergens. Subjects had refrained from using any medication for their asthma, rhinitis or allergy in the four weeks prior to taking biopsies and brushings. Healthy controls had normal spirometric values without airway hyperresponsiveness $\left(\mathrm{PC}_{20}>8 \mathrm{mg} / \mathrm{mL}\right)$, did not have a history of lung disease and were not atopic.

All subjects were non-smokers or ex-smokers ( $\geq 5$ pack years). Subjects had not smoked within 12 months prior to the study and they did not have any signs of a respiratory infection at the time of study visits. In the case of a respiratory infection, a 6-week recovery period was taken into account.

The study was approved by the hospital Medical Ethics Committee of the Academic Medical Centre in Amsterdam, and the study was registered in the Netherlands trial register (www.trialregister.nl) with identifier NTR2125. All patients gave written informed consent.

\section{Design}

This cross-sectional study consisted of two study visits. At least 14 days after the screening visit for checking inclusion and exclusion criteria, a fiberoptic bronchoscopy was performed during which 4 bronchial brushings were taken. Local anaesthesia of the larynx and lower airways was achieved using 1\% lignocaine. Subsequently, 4 nasal biopsies were taken from the lower edge of the inferior turbinate. Local anaesthesia was achieved by application of adrenalin and cocaine under the inferior turbinate without touching the biopsy site.

\section{Poly(l:C) stimulation of cultured primary epithelial cells}

Epithelial cells were isolated from bronchial brushings and nasal biopsies as previously described [11]. The cells were cultured to $80 \%$ confluence and pre-incubated with 
BEBM prior to stimulation. After 24 hours, the pre-incubation medium was removed and cells were exposed to BEBM containing $20 \mu \mathrm{g} / \mathrm{ml}$ Poly(I:C), a synthetic dsRNA, or with BEBM alone (control condition). RNA was extracted from the cells following 24 hours of stimulation. For a detailed description of the primary epithelial cell culture and RNA extraction, see Additional file 1: Methods of the online supplement.

\section{Analysis and statistics}

Microarray analysis was done by previously published method [11]. In short, Human Genome U133+ PM Genechip Array (Affymetrix inc., Santa Clara, CA, USA) was used for microarray analysis of genes. Next, Affymetrix Expression Console was used to analyze the array images using the robust multichip analysis (RMA) algorithm. Normalized data were further analysed using $\mathrm{R}$ (version 2.15) and the Bioconductor Limma package [15]. Differential gene expression was measured by empirical Bayes $\mathrm{t}$-statistics and $\mathrm{p}$-values were adjusted for false discovery rate correction [16]. The full microarray data was uploaded to the Gene Expression Omnibus (GEO) with accession number GSE51392.

GeneSpring GX12 (Agilent Technologies, Amstelveen, The Netherlands) was used for Gene ontology (GO) analysis. To investigate the overrepresentation of gene ontology groups we used the p-value adjusted for multiple testing by Benjamini-Yekutieli [17] (p-value $<0.01$ ). To enable validation of the microarray experiment changes in gene expression after poly(I:C) stimulation of nine genes were measured by independent real time PCR on the same starting material used for the microarray analysis (Additional file 1: Methods of the online supplement).

Sample size estimation was performed by a validated algorithm for microarray studies as published previously by our group [18], using data from two studies from others and ourselves $[19,20]$. This analysis showed that the present study had a False Discovery Rate of approximately $5 \%$ for detecting at least a 1.5-fold difference in gene expression when comparing three groups of 6 subjects at a significance level of 0.0001 ,

\section{Results}

The results of the validation by independent real time PCR are presented in Additional file 1: Table S1 and Additional file 2: Figure S1 of the online supplement.

\section{Poly(I:C)-induced changes in airway epithelial cells}

Sufficient RNA for gene expression profiling was obtained from both nasal and bronchial epithelium of 6 healthy controls, 5 patients with allergic rhinitis (1 patient was excluded because of insufficient RNA in the nasal sample) and 6 patients with both allergic rhinitis and allergic asthma. The baseline characteristics of the subjects included in the study are shown in Table 1 [11]. There were no differences between the groups in age and spirometry ( $p=0.4$ and $p=0.3$, respectively). As expected, $\mathrm{PC}_{20}$ was significantly lower in the patients with both asthma and rhinitis as compared to those with rhinitis alone and the controls. None of the healthy controls and only 1 out of 5 patients with rhinitis had a drop of $20 \%$ in $\mathrm{FEV}_{1}$ at the highest concentration of methacholinebromide $19.6 \mathrm{mg} / \mathrm{ml}$.

Overall, a strong response was observed after stimulation of the airway epithelial cells with poly(I:C). Using a cut-off of $\mathrm{p}<0.05$ (adjusted for multiple testing), 10163 and 8342 genes were significantly induced in the healthy upper and lower airway epithelium respectively, 9353 and 5190 genes in patients with allergic rhinitis, and 4919 and 5810 genes in patients with both asthma and allergic rhinitis (Additional file 1: Table S2 of the online supplement). The majority of the most highly up-regulated genes were interferon-related genes (CCL3, CCL4, CCL5, RSAD2, OAS1, OASL, MX1, MX2, IFI6, IFIT1, IFIT3, IFI44, IFI44L, CXCL10, CXCL11, TNFAIP6), which were induced in both upper and lower airways in all subjects (Tables 2 and 3).

\section{Functional characterization}

It appeared that $\sim 40 \%$ of the poly(I:C)-induced genes was altered in both upper and lower airways in all 3 subject-groups (see Figure 1A and 1B). When studying the functional characterization of these genes, many comparable GO-classes were significantly enriched in the upper and lower airways, e.g. response to virus, apoptotic process, antigen processing and presentation of peptide antigen via $M H C$ class $I$, and regulation of $I-\kappa B / N F-\kappa B$. The majority of genes related to response to virus were induced in all groups in the same direction (up- or down-regulated) (Additional file 1: Table S3A and S3B of the online supplement). Among the genes assigned to this GO-class were those involved in TLR3-signaling (TLR3, TICAM, TBK1, MYD88, IRAK3), interferons (IFNB1, IFNE, IFNK), various interferon receptors and interferon-induced proteins, cytokines (IL12A,IL23A, IL6) and particular

Table 1 Baseline characteristics

\begin{tabular}{|c|c|}
\hline & Subjects \\
\hline & $N=17$ \\
\hline Age $^{*}$ & $24(20-30)$ \\
\hline Female gender $(n)$ & 14 \\
\hline Prebronchodilator $\mathrm{FEV}_{1} \%$ predicted $\dagger$ & $109(11.0)$ \\
\hline$P C_{20} \ddagger^{* *}$ & $0.35(0.3)$ \\
\hline \multicolumn{2}{|c|}{$\begin{array}{l}\text { *Median (range). } \\
\text { †Mean (Standard Deviation). } \\
\text { ‡Geometric Mean (Geometric Standard Deviation). } \\
{ }^{* *} \text { Only from patients with both allergic asthma and rhinitis (none of the } \\
\text { healthy controls and only } 1 \text { out of } 5 \text { patients with rhinitis had a drop of } 20 \% \\
\text { in } \mathrm{FEV}_{1} \text { at the highest concentration of methacholine-bromide } 19.6 \mathrm{mg} / \mathrm{ml} \text { ). }\end{array}$} \\
\hline
\end{tabular}


Table 2 Most highly up-regulated genes in the upper airways

\begin{tabular}{|c|c|c|c|c|c|c|}
\hline \multirow[b]{2}{*}{ Gene ID } & \multicolumn{2}{|c|}{ Healthy } & \multicolumn{2}{|c|}{ Allergic rhinitis } & \multicolumn{2}{|c|}{ Asthma } \\
\hline & FC & adj.P.Val & FC & adj.P.Val & FC & adj.P.Val \\
\hline CCL5 & 517.58 & $2.27 \mathrm{E}-06$ & 717.90 & $1.11 \mathrm{E}-06$ & 148.81 & $2.63 \mathrm{E}-02$ \\
\hline AD2 & 260.58 & $6.48 \mathrm{E}-06$ & 638.34 & $9.05 \mathrm{E}-07$ & 98.63 & 2.63E-02 \\
\hline CMPK2 & 151.01 & 5.93E-05 & 469.49 & 4.62E-08 & 81.61 & 2.63E-02 \\
\hline ASL & 256.41 & $1.48 \mathrm{E}-06$ & 4 & 9.31 & 93.45 & 2 \\
\hline CCL3 & 277.19 & $3.04 \mathrm{E}-06$ & 334.76 & 2.77E-06 & 45.69 & 2.78E-02 \\
\hline 4orf7 & 249.61 & -07 & 319.09 & $=-06$ & 31.69 & 3.6 \\
\hline $1 \times 2$ & 115.45 & 3.43E-05 & 287.26 & $8.56 \mathrm{E}-08$ & 72.32 & 2.63E-02 \\
\hline 54 & 255.13 & 2.38E-06 & 243.83 & 6.17E-06 & 39.32 & 2.82E-02 \\
\hline I44L & 89.69 & $1.32 \mathrm{E}-04$ & 240.00 & 5.17E-07 & 58.14 & 2.82E-02 \\
\hline POBEC $3 \mathrm{~A}$ & 224.06 & $6.80 \mathrm{E}-08$ & 235.49 & $9.36 \mathrm{E}-07$ & 40.77 & 2.81E-02 \\
\hline XCL11 & 104.60 & $3.78 \mathrm{E}-06$ & 189.03 & $2.90 \mathrm{E}-06$ & 70.87 & 2.63E-02 \\
\hline XCL10 & 74.79 & 3.67E-05 & 175.30 & $1.38 \mathrm{E}-06$ & 72.35 & 2.63E-02 \\
\hline $\mathrm{ETD} \mathrm{CH}$ & 169.21 & 07 & 1 & 6 & 51 & 3 \\
\hline ESM1 & 109.38 & 7.55E-07 & 166.63 & 2.77E-06 & 34.37 & $2.78 \mathrm{E}-02$ \\
\hline 144 & 64.88 & $1.56 \mathrm{E}-04$ & 164.77 & 2.77E-06 & 42.51 & 3.06 \\
\hline OAS1 & 73.40 & $3.58 \mathrm{E}-05$ & 160.01 & $9.36 \mathrm{E}-07$ & 38.28 & $2.79 \mathrm{E}-02$ \\
\hline IFIT1 & 57.77 & 4.51E-04 & 150.43 & $2.08 \mathrm{E}-05$ & 40.36 & 2.81E-02 \\
\hline IFIT3 & 84.45 & 2.91E-05 & 149.76 & $2.16 \mathrm{E}-06$ & 41.00 & 2.63E-02 \\
\hline LAMP3 & 88.39 & $1.71 \mathrm{E}-05$ & 137.82 & $5.31 \mathrm{E}-06$ & 29.48 & 2.75E-02 \\
\hline TNFAIP6 & 137.00 & 4.06E-07 & 102.91 & $3.25 \mathrm{E}-05$ & 27.28 & $3.28 \mathrm{E}-02$ \\
\hline
\end{tabular}

$\mathrm{FC}=$ fold change; adj.P.Val $=p$-value adjusted for multiple testing .

cytokines related to type III interferons (IL28A, IL28B IL29), chemokines (CCL22, CCL4, CCL5), and transcription factors (IRF3, IRF7, IRF9, RELA, FOSL1).

\section{Upper and lower airways}

There were between-group differences in genes related to GO-class response to virus. Among the genes that were induced in all subjects except for patients with asthma were interferon involved genes (IL28B, IFNAR1), CCL22, and FOSL1 with respect to the upper airways, and several interferon involved genes (IRF3, IFNAR1, IFNB1, IFNGR1, IL28B) in the lower airways.

The upper airways of patients with asthma with concomitant allergic rhinitis demonstrated significantly fewer poly(I:C)-induced genes. In total, $57 \%$ of the induced genes was altered exclusively in the upper airways of either healthy subjects or allergic rhinitis patients and not in the upper airways of patients with asthma. Among these genes many GO classes were significantly overrepresented, amongst which many genes were assigned to metabolic process, mitochondrion and electron transport chain. Up to 2000 genes were assigned to metabolic process of which 347 genes overlap with class mitochondrion (Additional file 1: Table S4 of the online supplement). These mito-
Table 3 Most highly up-regulated genes in the lower airways

\begin{tabular}{|c|c|c|c|c|c|c|}
\hline \multirow[b]{2}{*}{ Gene ID } & \multicolumn{2}{|c|}{ Healthy } & \multicolumn{2}{|c|}{ Allergic rhinitis } & \multicolumn{2}{|c|}{ Asthma } \\
\hline & FC & $\overline{\text { adj.P.Val }}$ & FC & $\overline{\text { adj.P.Val }}$ & FC & adj.P.Val \\
\hline CCL5 & 736.54 & $6.09 \mathrm{E}-08$ & 322.77 & $1.61 \mathrm{E}-05$ & 231.87 & 9.60E-03 \\
\hline CMPK2 & 395.26 & $2.56 \mathrm{E}-08$ & 360.62 & $6.91 \mathrm{E}-06$ & 164.40 & 8.69E-03 \\
\hline RSAD2 & 363.02 & $1.47 \mathrm{E}-07$ & 304.55 & $6.91 \mathrm{E}-06$ & 167.47 & 9.76E-03 \\
\hline CXCL1 & 315.72 & $1.08 \mathrm{E}-07$ & 109.20 & $1.58 \mathrm{E}-04$ & 156.95 & 8.45E-03 \\
\hline IFIT1 & 307.08 & 9.93E-08 & 281.31 & 2.49E-05 & 161.84 & 1.05E-02 \\
\hline IFI44L & 274.95 & $2.91 \mathrm{E}-08$ & 211.91 & $1.08 \mathrm{E}-05$ & 113.56 & 9.51E-03 \\
\hline KCL10 & 263.55 & 2.97E-06 & 121.34 & 5.7 & 88.92 & 1.0 \\
\hline OASL & 241.59 & $6.78 \mathrm{E}-08$ & 138.85 & $5.11 \mathrm{E}-05$ & 160.96 & $8.11 \mathrm{E}-03$ \\
\hline$|F| 44$ & 236.92 & 4.06E-09 & 70.93 & 1.67 & 104.82 & 9 \\
\hline$M \times 2$ & 201.46 & $2.56 \mathrm{E}-08$ & 163.72 & $1.64 \mathrm{E}-05$ & 96.81 & 8.67E-03 \\
\hline$X 1$ & 140.44 & 1.45 & 175 & 1 & 01.01 & 3 \\
\hline IFI6 & 165.88 & $5.52 \mathrm{E}-10$ & 123.34 & $1.24 \mathrm{E}-05$ & 77.06 & 9.76E-03 \\
\hline רודם & 31.48 & 3.94E-04 & 137.90 & $2.06 \mathrm{E}-04$ & 25.92 & 1.11E-02 \\
\hline LAMP3 & 131.90 & $2.15 \mathrm{E}-06$ & 86.23 & $2.50 \mathrm{E}-04$ & 50.68 & 1.39E-02 \\
\hline XAF1 & 110.43 & $6.45 \mathrm{E}-08$ & 98.06 & 1.67E-05 & 61.68 & 7.99E-03 \\
\hline OAS1 & 109.84 & $1.13 \mathrm{E}-07$ & 86.84 & $5.10 \mathrm{E}-05$ & 47.06 & 1.05E-02 \\
\hline APOBEC3A & 101.03 & $3.84 \mathrm{E}-07$ & 86.19 & 8.06E-04 & 74.29 & 7.44E-03 \\
\hline S & 94.85 & 9.47E-08 & 88.51 & 5.73E-05 & 56.72 & 8.56E-03 \\
\hline CCL4 & 83.19 & $2.22 \mathrm{E}-04$ & 20.90 & $2.27 \mathrm{E}-02$ & 35.57 & 1.25E-02 \\
\hline CL3 & 69.05 & 7.38E-04 & 17.00 & 4.78E-02 & 35.62 & 1.27E-02 \\
\hline
\end{tabular}

$\mathrm{FC}=$ fold change; adj.P.Val $=p$-value adjusted for multiple testing

chondrial genes were mostly down-regulated. The latter class overlaps with genes assigned to the class electron transport chain, including several NADH dehydrogenase subcomplexes.

With respect to genes induced in the lower airways, significantly enriched GO-glasses emerged among genes exclusively induced in the lower airways of healthy subjects, including metabolic process, nucleus and mitochondrion. Among these genes, 915 genes were assigned to the GO-class metabolic process, of which 616 genes match with class nucleus and 191 with class mitochondrion (Additional file 1: Table S5 of the online supplement). Along with the upper airways, the GO-class mitochondrion was overrepresented among genes induced in the lower airways of both healthy controls and allergic rhinitis patients (Additional file 1: Table S6 of the online supplement). In addition, these mitochondrial genes were primarily down-regulated.

\section{Disease-specific gene expression induction}

We identified genes that were exclusively differentially expressed in patients with asthma and/or allergic rhinitis. We limited to genes that were up- or down-regulated by more than threefold (at least in one of the patient-groups) 

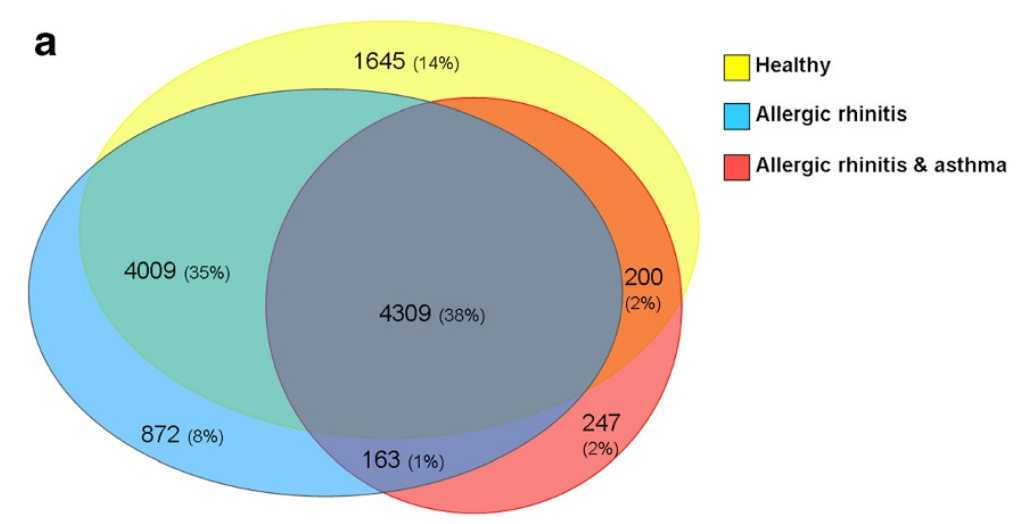

b

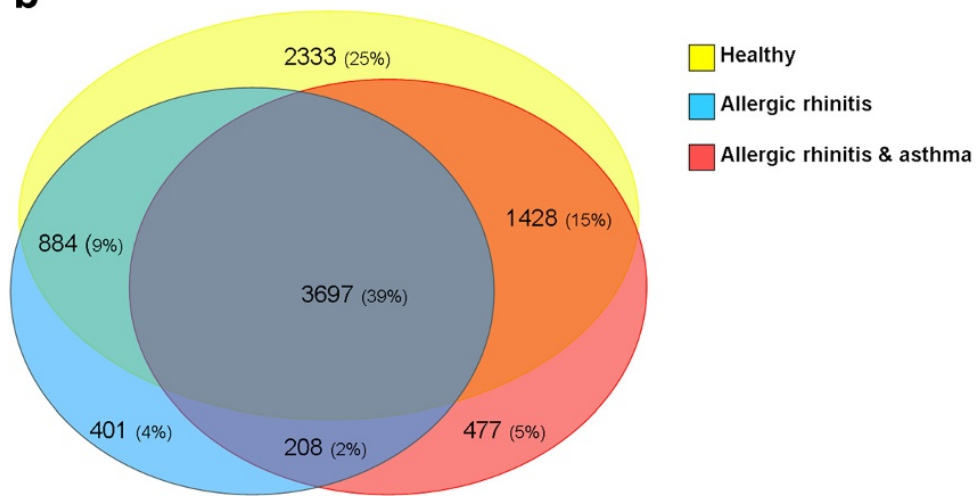

Figure 1 Venn-diagrams of up- and down-regulated genes. A. Venn-diagram of genes up- or down-regulated in the upper airways. B. Venn diagram of genes up- or down-regulated in the lower airways.

(see Tables 4 and 5). Among these genes were ciliary gene $B B S 1$, nebulette $(N E B L)$, nucleoside diphosphate kinase (NME7), the ubiquitous protein $A H N A K$, the calciumbinding S100A7A, myosin light chain kinase (MYLK), the cornulin gene $(C R N N)$, filaggrin ( $F L G)$, complement factor $\mathrm{B}(C F B)$, bone morphogenetic protein 6 (BMP6), adaptor protein $\mathrm{SH} 3 \mathrm{KBP} 1$, endoplasmatic reticulumassociated aminopeptidase 1 (ERAP1), and lysosomeassociated membrane protein 2 (LAMP2).

\section{Discussion}

This study shows the poly(I:C)-induced gene expression profiles of both upper and lower airway epithelium of patients with asthma, allergic rhinitis and healthy controls. The transcriptional response to poly(I:C) was characterized by a strong induction of genes. Among these genes were those involved in the response to virus, apoptotic processes and antigen presentation. Although the majority of genes involved in the response to poly(I:C) were similarly induced in upper and lower airways in all groups, we also observed differential expression, in particular with regard to impaired interferon expression in asthma. Furthermore, in contrast to healthy controls and rhinitis patients, the upper and lower airways of patients with asthma did not show poly(I:C)-induced down-regulation of mitochondrial genes. These findings are indicative of mitochondrial dysfunction in airway epithelium of patients with allergic asthma, and identify genes that may play a role in the altered viral response of diseased upper as well as lower airway epithelium.

To our knowledge, this is the first study that extensively profiles gene expression by microarray of the combined upper and lower airways epithelium in response to dsRNA of healthy individuals and patients with allergic rhinitis with or without allergic asthma. In our earlier study we describe the differences in gene expression profiles at baseline levels [11]. Interestingly, differential expression between the groups is mainly observed in both upper and lower airways, resulting in primarily comparable responses to dsRNA infection by the upper and lower airway epithelium within subjects. Furthermore, only small differences are observed between healthy controls and allergic rhinitis patients. Apparently, a pre-existing inflammatory background in allergic rhinitis does not grossly affect the response to poly(I:C). This suggests that the inflammatory pathways as induced by allergens and rhinovirus are mostly diverse. 


\begin{tabular}{|c|c|c|c|c|c|}
\hline Gene ID & $\begin{array}{l}\mathrm{FC} \\
\text { rhinitis }\end{array}$ & $\begin{array}{l}p \text {-value } \\
\text { rhinitis }\end{array}$ & $\begin{array}{l}\mathrm{FC} \\
\text { asthma }\end{array}$ & $\begin{array}{l}p \text {-value } \\
\text { asthma }\end{array}$ & Disease-specific \\
\hline LAMA3 & 10.87 & $<0.001$ & 1.62 & 0.031 & \multirow{20}{*}{$\begin{array}{l}\text { Significant } p \text {-value in } \\
\text { patients with allergic } \\
\text { rhinitis with or } \\
\text { without asthma }\end{array}$} \\
\hline SH3KBP1 & 9.12 & $<0.001$ & 5.13 & 0.027 & \\
\hline NME7 & 6.44 & $<0.001$ & 2.68 & 0.031 & \\
\hline ERAP1 & 5.06 & $<0.001$ & 3.76 & 0.026 & \\
\hline $\mathrm{MFI} 2$ & 5 & $<0.001$ & 3.39 & 0.042 & \\
\hline UBASH3B & 3.45 & $<0.001$ & 2.4 & 0.042 & \\
\hline NSD1 & 3.11 & 0.001 & 2.31 & 0.034 & \\
\hline SLC23A2 & -3.55 & $<0.001$ & -2.22 & 0.037 & \\
\hline ARHGAP5 & -3.57 & $<0.001$ & -2.12 & 0.039 & \\
\hline ATP6V0A2 & -3.79 & $<0.001$ & -2.57 & 0.03 & \\
\hline ANKH & -3.96 & $<0.001$ & -2.48 & 0.03 & \\
\hline WWTR1 & -4.03 & $<0.001$ & -2.41 & 0.048 & \\
\hline NEBL & -4.69 & 0.001 & -3.75 & 0.039 & \\
\hline MYO5A & -4.76 & $<0.001$ & -2.67 & 0.033 & \\
\hline LAMP2 & -5.02 & $<0.001$ & -3.05 & 0.035 & \\
\hline AHNAK & -5.02 & $<0.001$ & -3.33 & 0.031 & \\
\hline RAB22A & -5.93 & $<0.001$ & -3.18 & 0.031 & \\
\hline PPAT & -6.37 & $<0.001$ & -2.72 & 0.044 & \\
\hline TFRC & -9.93 & $<0.001$ & -5.63 & 0.028 & \\
\hline CCNB2 & -15.44 & $<0.001$ & -5.37 & 0.04 & \\
\hline IQCG & 4.48 & 0.012 & 1.07 & 0.6 & \multirow{2}{*}{$\begin{array}{l}\text { In patients with } \\
\text { allergic rhinitis }\end{array}$} \\
\hline BBS1 & -3.23 & $<0.001$ & -1.05 & 0.8 & \\
\hline RBM8A & -1.7 & 0.07 & -3.01 & 0.039 & \multirow{3}{*}{$\begin{array}{l}\text { In patients with } \\
\text { allergic rhinitis } \\
\text { with asthma }\end{array}$} \\
\hline SSR1 & -2.38 & 0.2 & -3.74 & 0.044 & \\
\hline CLN8 & -2.53 & 0.06 & -5.34 & 0.028 & \\
\hline
\end{tabular}

$\mathrm{FC}=$ fold change; $p$-value $=p$-value adjusted for multiple testing.

Our finding of similar induction of genes involved in inflammatory responses in the airway epithelium in all three groups extends previous results. In a previous study examining the transcriptional response of RV-infected primary bronchial epithelial cells, pro-inflammatory pathways were similarly induced in asthma and controls [7]. Our data show that this also holds for allergic rhinitis. Hence, according to these results, the majority of inflammatory genes in epithelial cells are induced by viruses in both the healthy and diseased states. However, this can not be extrapolated to COPD, in which bronchial epithelial cells demonstrated enhanced pro-inflammatory and antiviral reactions to RV as compared to healthy controls [21].

Still, we also observed several interferon related genes that were induced in healthy controls and rhinitis patients, though not in asthma patients (especially the lower airways). Interferon- $\beta 1$ (IFNB1) was significantly upregulated in all cultures of all groups except for the lower airways of asthma patients. IL28B, known as interferon- $\lambda 3$, was also significantly induced in both upper and lower airways of allergic rhinitis patients and controls, though not in asthma patients. This impaired induction in asthma was not due to high baseline gene expression prior to stimulation. IFN- $\beta$ s and IFN- $\lambda$ s play a major role in the host defense against respiratory viral infections $[8,22]$. These results confirm and extend previous studies on RV-infected primary bronchial epithelial cells, demonstrating reduced IFN- $\beta$ [9] and IFN- $\lambda$ [8] response in asthma, suggesting a higher susceptibility to viral infections and thereby to exacerbations. This may partly explain the high correlation between viral respiratory tract infections and asthma exacerbations [1]. Nevertheless, when considering the most highly up-regulated genes, a considerable proportion of interferon-related genes appear to be induced in all groups. This fits in with very recent data in human bronchial smooth muscle cells, also showing production of IFNs by poly(I:C) [23]. Notably, the upregulation of these interferon-related genes tends to be much less in patients with asthma, although a larger fold change difference of a gene might not necessarily be linked to larger impact on a protein pathway.

The loss of mitochondrial and other metabolic gene down-regulation to dsRNA in asthma as compared to healthy controls and allergic rhinitis is in keeping with previously reported modifications in mitochondrial/metabolic function in A549 cells and animal models of allergic inflammation. These studies demonstrated that mitochondrial dysfunction exacerbates antigen-driven allergic airway inflammation by increased generation of reactive oxygen species (ROS), which induces oxidative stress in the lungs [24]. Environmental factors such as allergens, ozone, and viruses increase ROS production thereby interactively promoting allergic inflammation $[25,26]$. Second, since viral replication is dependent on host resources, down-regulation of mitochondrial function in a healthy state may prevent energy production to provide this replication. A recent review describes previous studies that have observed modulation of mitochondrial functions during different viral infections [27]. That viral replication depends on mitochondrial biogenesis was previously observed during Human Cytomegalovirus infection [28]. Interestingly, this loss of down-regulated genes in our study was observed in both upper and lower airways of patients with asthma, suggesting changed host characteristics of the upper airways in patients with allergic rhinitis plus asthma as compared to those with allergic rhinitis alone. This implies at least an interaction between asthma and rhinitis in the response to respiratory viruses. Since we did not include asthma patients without allergic rhinitis we can only speculate about the role of the presence of allergic rhinitis in asthma. However, in our previous study we found a large impact of allergic rhinitis on the differences in epithelial gene expression between 


\begin{tabular}{|c|c|c|c|c|c|}
\hline Gene ID & $\begin{array}{l}\text { FC } \\
\text { rhinitis }\end{array}$ & $\begin{array}{l}p \text {-value } \\
\text { rhinitis }\end{array}$ & $\begin{array}{l}\mathrm{FC} \\
\text { asthma }\end{array}$ & $\begin{array}{l}p \text {-value } \\
\text { asthma }\end{array}$ & Disease-specific \\
\hline$\overline{C F B}$ & 42.13 & 0.001 & 30.04 & 0.009 & \multirow{10}{*}{$\begin{array}{l}\text { Significant } p \text {-value in } \\
\text { patients with allergic } \\
\text { rhinitis with or } \\
\text { without asthma }\end{array}$} \\
\hline $\mathrm{MB}$ & 8.95 & 0.005 & 2.73 & 0.017 & \\
\hline MAMDC2 & 3.2 & 0.009 & 1.58 & 0.06 & \\
\hline XRCC6BP1 & -2.01 & 0.005 & -3.06 & 0.01 & \\
\hline C4orf32 & -3.06 & 0.027 & -1.36 & 0.018 & \\
\hline MPPE1 & -3.31 & 0.016 & -3.83 & 0.026 & \\
\hline NEBL & -3.8 & 0.009 & -3.35 & 0.012 & \\
\hline GPC6 & -5.11 & 0.001 & -2.31 & 0.022 & \\
\hline CYP1B1 & -6.31 & 0.027 & -2.39 & 0.027 & \\
\hline CLN8 & -6.39 & 0.001 & -5 & 0.011 & \\
\hline SHISA2 & 4.61 & 0.015 & 1.29 & 0.4 & \multirow{12}{*}{$\begin{array}{l}\text { In patients with } \\
\text { allergic rhinitis }\end{array}$} \\
\hline S100A7A & 4.07 & 0.017 & 1.38 & 0.4 & \\
\hline NPFFR2 & 3.7 & 0.043 & 1.26 & 0.2 & \\
\hline $\mathrm{RDH} 10$ & 3.37 & 0.016 & 1.1 & 0.6 & \\
\hline BMP6 & 3.36 & 0.015 & 1.11 & 0.6 & \\
\hline RNF141 & -3.04 & 0.005 & 1.08 & 0.3 & \\
\hline C12orf28 & -3.08 & 0.037 & -1.14 & 0.4 & \\
\hline LOC148189 & -3.23 & 0.023 & -1.13 & 0.4 & \\
\hline CRNN & -3.75 & 0.021 & -1.07 & 0.9 & \\
\hline PCK2 & -4.16 & 0.024 & -1.25 & 0.2 & \\
\hline $\mathrm{CTH}$ & -5.08 & 0.046 & -1.23 & 0.4 & \\
\hline FLG & -5.17 & 0.004 & -1.53 & 0.2 & \\
\hline FANCD2 & 1.03 & 0.2 & -3.03 & 0.014 & \multirow{3}{*}{$\begin{array}{l}\text { In patients with } \\
\text { allergic rhinitis } \\
\text { with asthma }\end{array}$} \\
\hline MYLK & -1.03 & 0.5 & -3.1 & 0.005 & \\
\hline SSR1 & -1.16 & 0.4 & -3.13 & 0.025 & \\
\hline
\end{tabular}

$\mathrm{FC}=$ fold change; $p$-value $=p$-value adjusted for multiple testing.

upper and lower airways, influencing the lower airways as well [11]. Therefore, we assume that allergic rhinitis affects both upper and lower epithelial responses to viruses in patients with asthma. This would further explain mainly similar responses to dsRNA by both nasal and bronchial epithelium within subject-groups.

Among the disease-specific genes that were induced in allergic rhinitis patients with or without asthma but not in healthy controls, there were genes (ERAP1, LAMP2) that have been shown to be involved in antigen presentation $[29,30]$. Furthermore, several genes (SH3KBP1, CRNN, FLG, S100A7A) related to allergic inflammation [31-34] were either induced in allergic rhinitis patients with or without asthma (SH3KB1) or in allergic rhinitis patients only (CRNN, FLG, S100A7A). The genes BMP6, $C F B$ and MYLK have previously been associated with airway inflammation and hyperresponsiveness [35-37]. Of these genes, $C F B$ was induced in all patients, whereas $B M P 6$ solely in allergic rhinitis patients and MYLK in allergic rhinitis patients with asthma. The AHNAK gene, induced in allergic rhinitis patients with or without asthma, was previously associated with asthma susceptibility [38]. Interestingly, there was also induction of ciliary genes (BBS1, NEBL, NME7) [39-41] of which $N E B L$ and $N M E 7$ in allergic rhinitis patients with or without asthma while $B B S 1$ exclusively in patients with allergic rhinitis. Mucociliary clearance is essential for the pulmonary defense [42], and ciliary dysfunction has been previously related to asthma severity [43].

The strength of our study is that we have collected primary epithelial cells from both upper and lower airways from the same individuals in three different conditions (healthy, allergic rhinitis, allergic rhinitis and asthma). Furthermore, we were able to extensively analyse gene expression by using microarray, which was confirmed by PCR analysis. Nevertheless, the study has some limitations. Firstly, we included relatively few individuals per group. We carefully calculated this samples size by setting the false-discovery rate at approximately $5 \%$. A larger sample size would have allowed capturing smaller differences in expression profile or greater differences in genes that display a large variation in expression per individual. As a consequence we purposely focused on paired differences before and after poly(I:C) stimulation instead of comparing unpaired expression between the different subject groups. In addition to the original power calculation mentioned, the statistics used to measure differential expression applied the Benjamini and Hochberg adjustment of p-values for multiple testing. This correction uses a smaller significance level, inevitably reducing the power of the analysis. This will have led to false-negative results on poly $(\mathrm{I}: \mathrm{C})$-induced genes, but it purposely limited the risk of false positive discovery.

We did not use a real virus as a stimulus, but we used poly(I:C) instead. Although a real virus such as RV would have been preferable, in order to match the in vivo conditions, dsRNA is an adequate surrogate marker for RV. Toll-like receptor 3 (TLR3) is required for the sensing of RV produced dsRNA [10] and the TLR3 ligand poly (I:C) was found previously to be a very effective stimulus of airway epithelial cells [44,45]. Since actual steroid exposure will change the expression of many genes, patients were prohibited steroid usage for 4 weeks before sampling. In fact, all allergic rhinitis patients were entirely steroid naive and only one asthma patient used topical steroids and one asthma patient used inhaled steroids 4 weeks prior to recruitment. We cannot exclude carry-over effects of steroids even over this time span. Finally, culturing of cells will affect gene expression levels since conditions are no longer the same as in the airways. This seems to be inevitable. Alternative procedures to obtain epithelial cells such as laser capture or direct measurement after isolation might mitigate these effects of cell culturing, but will 
introduce new biases introduced by contamination by other cell types and/or the (enzymatic) isolation procedures themselves. However, as we compared epithelial cells from the same individuals, the standardized culturing of these cells should have affected nose and bronchial epithelial cells similarly.

The currently observed disease-related differences in viral-induced gene expression of upper and lower airways between patients with allergic rhinitis and asthma and healthy controls may have clinical implications. First, these results help to understand the mechanistic pathways of the mutual interaction between asthma and rhinitis, for which there is considerable clinical evidence [46]. Second, the current analysis identified several new genes whilst confirming other genes from previous findings. This may provide potential targets with respect to mitochondrial dysfunction and interferon involved genes for drug-discovery studies and for treatment of exacerbations in patients with combined upper and lower airway disease.

\section{Conclusions}

In conclusion, we demonstrated that there are differences between rhinitis patients with and without asthma in the epithelial expression of dsRNA-induced genes, which are related to interferons and mitochondrial function. This appears to be manifested in both the upper and lower airways, suggesting mainly comparable responses to dsRNA infection in upper and lower airway epithelium within subjects. These data identify host-virus interactions in asthma, rhinitis and controls, which is required for developing targeted preventative and therapeutic interventions in asthma exacerbations.

\section{Additional files}

Additional file 1: Table S1. Validatory PCR of housekeeping genes and significantly different genes. Table S2. dsRNA-induced genes in upper and lower airways. Table S3A. Genes assigned to GO-cluster response to virus induced in the upper airways. Table S3B. Genes assigned to GO-cluster esponse to virus induced in the lower airways Table S4. Genes induced in the upper airways of healthy controls and allergic rhinitis patients, assigned to GO cluster Mitochondrion. Table S5. Genes induced in the lower airways of healthy controls, assigned to GO cluster Mitochondrion. Table S6. Genes induced in the lower airways of healthy controls and allergic rhinitis patients, assigned to $\mathrm{GO}$ cluster Mitochondrion.

Additional file 2: Figure S1. Correlation plot of real-time PCR data and microarray results. FCs were logtranformed.

\begin{abstract}
Abbreviations
ARIA: Allergic rhinitis and its impact on asthma; BEBM: Bronchial epithelial basal medium; dsRNA: Double-stranded RNA; FC: Fold change; GINA: Global initiative for asthma; GO: Gene ontology; PCR: Polymerase chain reaction; RV: Rhinovirus.
\end{abstract}

\section{Competing interests}

All authors declare they have no competing interests

\section{Authors' contributions}

AHW, WJF, EHB, PJS, CMD participated in the study's conception and design. AHW recruited the subjects. AHW and SL performed the experiments. AHW and $\mathrm{AHZ}$ performed the statistical analysis and all authors contributed in the interpretation of data, preparation and editing of the manuscript for intellectual content. All authors read and approved the final manuscript.

\section{Author details}

'Department of Respiratory Medicine, Academic Medical Center, University of Amsterdam, Meibergdreef 9, 1105 AZ, Amsterdam, The Netherlands. ${ }^{2}$ Department of Clinical Epidemiology, Biostatistics \& Bioinformatics, Academic Medical Center, University of Amsterdam, Amsterdam, The Netherlands. ${ }^{3}$ Department of Otorhinolaryngology, Academic Medical Center, University of Amsterdam, Amsterdam, The Netherlands.

Received: 10 October 2013 Accepted: 17 January 2014

Published: 29 January 2014

\section{References}

1. Busse WW, Lemanske RF Jr, Gern JE: Role of viral respiratory infections in asthma and asthma exacerbations. Lancet 2010, 376:826-834.

2. Corne JM, Marshall C, Smith S, Schreiber J, Sanderson G, Holgate ST, Johnston SL: Frequency, severity, and duration of rhinovirus infections in asthmatic and non-asthmatic individuals: a longitudinal cohort study. Lancet 2002, 359:831-834.

3. Sulakvelidze I, Inman MD, Rerecich T, O'Byrne PM: Increases in airway eosinophils and interleukin-5 with minimal bronchoconstriction during repeated low-dose allergen challenge in atopic asthmatics. Eur Respir J 1998, 11:821-827.

4. Green RM, Custovic A, Sanderson G, Hunter J, Johnston SL, Woodcock A: Synergism between allergens and viruses and risk of hospital admission with asthma: case-control study. BMJ 2002, 324:763.

5. Cruz AA, Popov T, Pawankar R, Annesi-Maesano I, Fokkens W, Kemp J, Ohta K, Price D, Bousquet J: Common characteristics of upper and lower airways in rhinitis and asthma: ARIA update, in collaboration with $\mathrm{GA}(2)$ LEN. Allergy 2007, 62(Suppl 84):1-41.

6. Lopez-Souza N, Favoreto S, Wong H, Ward T, Yagi S, Schnurr D, Finkbeiner WE, Dolganov GM, Widdicombe JH, Boushey HA, Avila PC: In vitro susceptibility to rhinovirus infection is greater for bronchial than for nasal airway epithelial cells in human subjects. J Allergy Clin Immunol 2009, 123:1384-1390.

7. Bochkov YA, Hanson KM, Keles S, Brockman-Schneider RA, Jarjour NN, Gern JE: Rhinovirus-induced modulation of gene expression in bronchial epithelial cells from subjects with asthma. Mucosal Immunol 2010, 3:69-80.

8. Contoli M, Message SD, Laza-Stanca V, Edwards MR, Wark PA, Bartlett NW, Kebadze T, Mallia P, Stanciu LA, Parker HL, Slater L, Lewis-Antes A, Kon OM, Holgate ST, Davies DE, Kotenko SV, Papi A, Johnston SL: Role of deficient type III interferon-lambda production in asthma exacerbations. Nat Med 2006, 12:1023-1026.

9. Wark PA, Johnston SL, Bucchieri F, Powell R, Puddicombe S, Laza-Stanca V, Holgate ST, Davies DE: Asthmatic bronchial epithelial cells have a deficient innate immune response to infection with rhinovirus. J Exp Med 2005, 201:937-947.

10. Wang Q, Nagarkar DR, Bowman ER, Schneider D, Gosangi B, Lei J, Zhao Y, McHenry CL, Burgens RV, Miller DJ, Sajjan U, Hershenson MB: Role of double-stranded RNA pattern recognition receptors in rhinovirusinduced airway epithelial cell responses. J Immunol 2009, 183:6989-6997.

11. Wagener $A H$, Zwinderman AH, Luiten S, Fokkens WJ, Bel EH, Sterk PJ, van Drunen CM: The impact of allergic rhinitis and asthma on human nasal and bronchial epithelial gene expression. PLoS One 2013, 8:e80257.

12. From the Global Strategy for Asthma Management and Prevention, Global Initiative for Asthma (GINA). 2012 http://www.ginasthma.org.

13. Crapo RO, Casaburi R, Coates AL, Enright PL, Hankinson JL, Irvin CG, MacIntyre NR, McKay RT, Wanger JS, Anderson SD, Cockcroft DW, Fish JE, Sterk PJ: Guidelines for methacholine and exercise challenge testing-1999. This official statement of the American Thoracic Society was adopted by the ATS Board of Directors, July 1999. Am J Respir Crit Care Med 2000, 161:309-329.

14. Bousquet J, Khaltaev N, Cruz AA, Denburg J, Fokkens WJ, Togias A, Zuberbier T, Baena-Cagnani CE, Canonica GW, van Weel C, et al: Allergic Rhinitis and its Impact on Asthma (ARIA) 2008 update (in collaboration 
with the World Health Organization, GA(2)LEN and AllerGen). Allergy 2008, 63(Suppl 86):8-160

15. Smyth GK: Linear models and empirical Bayes methods for assessing differential expression in microarray experiments. Stat Appl Genet Mol Biol 2004, 3:3.

16. Hochberg Y, Benjamini Y: More powerful procedures for multiple significance testing. Stat Med 1990, 9:811-818.

17. Benjamini Y, Yekutieli D: The control of the false discovery rate in multiple testing under dependency. Ann Statist 2001, 29:1165-1188.

18. Ferreira JA, Zwinderman A: Approximate sample size calculations with microarray data: an illustration. Stat Appl Genet Mol Biol 2006, 5:Article 25.

19. Vroling $A B$, Jonker MJ, Luiten $S$, Breit $T M$, Fokkens WJ, van Drunen CM: Primary nasal epithelium exposed to house dust mite extract shows activated expression in allergic individuals. Am J Respir Cell Mol Biol 2008, 38:293-299.

20. Woodruff PG, Boushey HA, Dolganov GM, Barker CS, Yang YH, Donnelly S, Ellwanger A, Sidhu SS, Dao-Pick TP, Pantoja C, Erle DJ, Yamamoto KR, Fahy $\mathrm{JV}$ : Genome-wide profiling identifies epithelial cell genes associated with asthma and with treatment response to corticosteroids. Proc Natl Acad Sci U S A 2007, 104:15858-15863.

21. Baines KJ, Hsu AC, Tooze M, Gunawardhana LP, Gibson PG, Wark PA: Novel immune genes associated with excessive inflammatory and antiviral responses to rhinovirus in COPD. Respir Res 2013, 14:15.

22. Khaitov MR, Laza-Stanca V, Edwards MR, Walton RP, Rohde G, Contoli M, Papi A, Stanciu LA, Kotenko SV, Johnston SL: Respiratory virus induction of alpha-, beta- and lambda-interferons in bronchial epithelial cells and peripheral blood mononuclear cells. Allergy 2009, 64:375-388.

23. Calven J, Yudina Y, Uller L: Rhinovirus and dsRNA induce RIG-I-Like receptors and expression of Interferon beta and lambda1 in human bronchial smooth muscle cells. PLoS One 2013, 8:e62718.

24. Aguilera-Aguirre L, Bacsi A, Saavedra-Molina A, Kurosky A, Sur S, Boldogh I: Mitochondrial dysfunction increases allergic airway inflammation. J Immunol 2009, 183:5379-5387.

25. Bowler RP: Oxidative stress in the pathogenesis of asthma. Curr Allergy Asthma Rep 2004, 4:1 16-122.

26. Jamaluddin M, Tian B, Boldogh I, Garofalo RP, Brasier AR: Respiratory syncytial virus infection induces a reactive oxygen species-MSK1phospho-Ser-276 RelA pathway required for cytokine expression. J Virol 2009, 83:10605-10615.

27. El-Bacha T, Da Poian AT: Virus-induced Changes in mitochondria bioenergetics as potential targets for therapy. Int I Biochem Cell Biol 2013, 45:41-46.

28. Kaarbø M, Ager-Wick E, Osenbroch PØ, Kilander A, Skinnes R, Müller F, Eide $L$ : Human Cytomegalovirus infection increases mitochondrial biogenesis. Mitochondrion 2011, 11:935-945.

29. Firat E, Saveanu L, Aichele P, Staeheli P, Huai J, Gaedicke S, Nil A, Besin G, Kanzler B, van Endert P, Niedermann G: The role of endoplasmic reticulum-associated aminopeptidase 1 in immunity to infection and in cross-presentation. J Immunol 2007, 178:2241-2248.

30. Zhou D, Li P, Lin Y, Lott JM, Hislop AD, Canaday DH, Brutkiewicz RR, Blum JS: Lamp-2a facilitates MHC class II presentation of cytoplasmic antigens. Immunity 2005, 22:571-581.

31. Lieden A, Ekelund E, Kuo IC, Kockum I, Huang CH, Mallbris L, Lee SP, Seng LK, Chin GY, Wahlgren CF, Palmer CN, Bjorksten B, Stahle M, Nordenskjold M, Bradley M, Chua KY, D'Amato M: Cornulin, a marker of late epidermal differentiation, is down-regulated in eczema. Allergy 2009, 64:304-311.

32. Molfetta R, Belleudi F, Peruzzi G, Morrone S, Leone L, Dikic I, Piccoli M, Frati L, Torrisi MR, Santoni A, Paolini R: CIN85 regulates the ligand-dependent endocytosis of the lgE receptor: a new molecular mechanism to dampen mast cell function. J Immunol 2005, 175:4208-4216.

33. Sandilands A, Smith FJ, Irvine AD, McLean WH: Filaggrin's fuller figure: a glimpse into the genetic architecture of atopic dermatitis. J Invest Dermatol 2007, 127:1282-1284

34. Wolf R, Lewerenz V, Buchau AS, Walz M, Ruzicka T: Human S100A15 splice variants are differentially expressed in inflammatory skin diseases and regulated through Th1 cytokines and calcium. Exp Dermatol 2007, 16:685-691.

35. Jiang H, Rao K, Halayko AJ, Liu X, Stephens NL: Ragweed sensitizationinduced increase of myosin light chain kinase content in canine airway smooth muscle. Am J Respir Cell Mol Biol 1992, 7:567-573.
36. Rosendahl A, Pardali E, Speletas M, Ten DP, Heldin CH, Sideras P: Activation of bone morphogenetic protein/Smad signaling in bronchial epithelial cells during airway inflammation. Am J Respir Cell Mol Biol 2002, 27:160-169.

37. Taube C, Thurman JM, Takeda K, Joetham A, Miyahara N, Carroll MC, Dakhama A, Giclas PC, Holers VM, Gelfand EW: Factor B of the alternative complement pathway regulates development of airway hyperresponsiveness and inflammation. Proc Natl Acad Sci U S A 2006, 103:8084-8089.

38. Ungvari I, Hullam G, Antal P, Kiszel PS, Gezsi A, Hadadi E, Virag V, Hajos G, Millinghoffer A, Nagy A, Kiss A, Semsei AF, Temesi G, Melegh B, Kisfali P, Szell M, Bikov A, Galffy G, Tamasi L, Falus A, Szalai C: Evaluation of a partial genome screening of two asthma susceptibility regions using bayesian network based bayesian multilevel analysis of relevance. PLoS One 2012 7:e33573.

39. Chhin B, Pham JT, El ZL, Kaiser K, Merrot O, Bouvagnet P: Identification of transcripts overexpressed during airway epithelium differentiation. Eur Respir J 2008, 32:121-128.

40. Inglis PN, Boroevich KA, Leroux MR: Piecing together a ciliome. Trends Genet 2006, 22:491-500

41. Lai CK, Gupta N, Wen X, Rangell L, Chih B, Peterson AS, Bazan JF, Li L, Scales SJ: Functional characterization of putative cilia genes by high-content analysis. Mol Biol Cell 2011, 22:1104-1119.

42. Knowles MR, Boucher RC: Mucus clearance as a primary innate defense mechanism for mammalian airways. J Clin Invest 2002, 109:571-577.

43. Thomas B, Rutman A, Hirst RA, Haldar P, Wardlaw AJ, Bankart J, Brightling CE, O'Callaghan C: Ciliary dysfunction and ultrastructural abnormalities are features of severe asthma. J Allergy Clin Immunol 2010, 126:722-729.

44. Kawai T, Akira S: Innate immune recognition of viral infection. Nat Immunol 2006, 7:131-137.

45. Sha Q, Truong-Tran AQ, Plitt JR, Beck LA, Schleimer RP: Activation of airway epithelial cells by toll-like receptor agonists. Am J Respir Cell Mol Biol 2004, 31:358-364.

46. Bousquet J, Schunemann HJ, Samolinski B, Demoly P, Baena-Cagnani CE, Bachert C, Bonini S, Boulet LP, Bousquet PJ, Brozek JL, et al: Allergic Rhinitis and its Impact on Asthma (ARIA): achievements in 10 years and future needs. J Allergy Clin Immunol 2012, 130:1049-1062.

doi:10.1186/1465-9921-15-9

Cite this article as: Wagener et al:: dsRNA-induced changes in gene expression profiles of primary nasal and bronchial epithelial cells from patients with asthma, rhinitis and controls. Respiratory Research 2014 15:9.

\section{Submit your next manuscript to BioMed Central and take full advantage of:}

- Convenient online submission

- Thorough peer review

- No space constraints or color figure charges

- Immediate publication on acceptance

- Inclusion in PubMed, CAS, Scopus and Google Scholar

- Research which is freely available for redistribution 